\title{
ANALISIS DAN MITIGASI RISIKO RANTAI PASOK MINYAK PALA KABUPATEN ACEH SELATAN MENGGUNAKAN FMECA
}

\section{RISK ANALYSYS AND MITIGATION OF SOUTH ACEH NUTMEG OILS SUPPLY CHAIN USING FMECA}

\author{
Rachman Jaya $^{1 *)}$, M. Ismail ${ }^{1)}$, Yusriana ${ }^{2)}$, Iskandar Mirza'), Mehran'), Asis ${ }^{1)}$, Basri A. Bakar ${ }^{1)}$ \\ ${ }^{1)}$ Balai Pengkajian Teknologi Pertanian Aceh \\ Jl. Panglima Nyak Makam No.27 Lampineung, Banda Aceh, Indonesia. \\ Email: jaya.rachman@yahoo.co.id \\ ${ }^{2)}$ Program Studi Teknologi Hasil Pertanian, Fakultas Pertanian Universitas Syiah Kuala, Darussalam, Banda Aceh, Indonesia
}

Makalah: Diterima 19 September 2018; Diperbaiki 18 Maret 2019; Disetujui 29 Maret 2019

\begin{abstract}
Nutmeg oil from South Aceh is one of the main commodities in Indonesian essential oils trading. Specially, 70-80\% Indonesian nutmeg oil trading origin is from South Aceh. On the other hand, a business risk of nutmeg oil is on collectors district, so these actors to be critical point in nutmeg oil production. The objectives of this research were to determine risk factors and to design risk mitigation in nutmeg oils supply chain on South Aceh. The technique used was Failure Mode and Effective Critically Analysis (FMECA). Data collecting according to expert's survey and background and qualification of experts were academicians, researcher, and practitioners. Academicians and researchers were PhD holders with 10 years experience in agriculture development, practitioners graduate minimally, practitioners were bachelor degree holders with 15 years experience. The result of the study showed that on farmers, the highest risks were on pest and disease attack and price fluctuation, meanwhile on agro-industry actors, the highest risks were on quality product fulfillment and price fluctuation. To arrange over supply, policy analysis was needed for the establishment of business units initiated by local governments.
\end{abstract}

Keywords: nutmeg oils, South Aceh, FMECA

\section{ABSTRAK}

Minyak pala Aceh Selatan memiliki peranan penting dalam perdagangan minyak atsiri asal Indonesia. 70-80\% perdagangan minyak pala Indonesia berasal dari Aceh Selatan. Pada sisi yang lain, risiko usaha terbesar minyak pala berada pada pedagang pengepul tingkat kabupaten, sehingga aktor ini menjadi titik kritis dalam usaha produksi minyak pala. Tujuan dari penelitian adalah menetukan faktor-faktor risiko dan desain mitigasi risiko dalam struktur rantai pasok minyak pala di Aceh Selatan. Teknik analisis menggunakan Failure Mode and Effective Critically Analysis (FMECA). Data penelitian dari survei pakar dengan latar belakang dan kualifikasi pakar akademisi, praktisi dan peneliti. Akademisi dan peneliti minimal bergelar doktor (S3) dan berpengalaman 10 tahun pada bidang pengembangan pertanian, praktisi minimal bergelar sarjana (S1), dan berpengalaman minimal 15 tahun. Hasil penelitian menunjukkan bahwa pada pelaku petani risiko tertinggi adalah aspek serangan hama dan penyakit serta fluktuasi harga, pada pelaku pedagang pengepul desa, risiko tertinggi pada fluktuasi harga jual, pada pedagang pengepul kecamatan yang juga sebagai agroindustri pada pemenuhan mutu produk dan over produksi di eksportir. Pada pelaku eksportir berupa fluktuasi harga minyak pala/atsiri dunia. Secara keseluruhan mitigasi yang harus dilakukan pada pelaku petani dengan perbaikan sistem budidaya, yaitu mengaplikasikan bibit sistem sambung pucuk yang relatif tahan terhadap serangan hama dan penyakit, sedangkan pada agroindustri negosiasi kontrak dengan eksportir dengan dukungan pemerintah daerah. Untuk kelebihan produksi diperlukan kebijakan pembentukan badan usaha, yang diinisiasi oleh pemerintah daerah dengan pola bisnis berorientasi profit yang murni dilaksanakan oleh pelaku bisnis.

Kata kunci: minyak pala, Kabupaten Aceh Selatan, FMECA

\section{PENDAHULUAN}

Bagi Provinsi Aceh, khususnya Kabupaten Aceh Selatan, tanaman pala (Myristica Fragrans Hountt) merupakan salah satu komoditas utama ekspor non migas, biji dan kulitnya dapat diolah menjadi minyak atsiri (minyak pala) dan sebagai bahan rempah-rempah. Daging buahnya dapat juga diolah untuk berbagai macam produk makanan yang nilai ekonominya cukup tinggi seperti sirup pala dan manisan pala. Total luas lahan pala di Provinsi Aceh mencapai 17,264 ha, dimana 87\% terdapat di Kabupaten Aceh Selatan, terutama di Kecamatan Pasie Raja, Kluet Utara, Kluet Tengah, Samadua, Sawang dan Tapaktuan, sisanya terdapat di Kabupaten Aceh Barat Daya, yang pada awalnya merupakan bagian dari Kabupaten Aceh Selatan (Direktorat Jenderal Perkebunan, 2017; BPS Kabupaten Aceh Selatan, 2017). 
Pada satu dekade terakhir, trend produksi pala mengalami peningkatan (Gambar 1), demikian juga dengan trend luas lahan pala di Aceh Selatan (BPS Aceh Selatan, 2017). Fakta ini justru berbanding terbalik dengan berkurangnya jumlah pohon pala yang ada saat ini (kondisi eksisting). Berkurangnya jumlah pohon pala disebabkan oleh serangan hama penggerek batang dan jamur akar putih (Harni et al., 2011). Hasil kajian BPTP Aceh (2018) bahwa penurunan populasi pohon pala di Aceh Selatan mencapai $87 \%$, nilai ini juga hampir sama dengan yang terjadi di Kabupaten Maluku Tengah (Kalay et al., 2015). Hasil kajian Mustafril (2017), menunjukkan bahwa 70-80\% minyak pala Indonesia berasal dari Aceh Selatan, sisanya dari Sumatera Barat dan Jawa Barat. Produksi minyak pala Aceh diperkirakan 350-400 ton per tahun pada tahun 2017, dengan harga berkisar Rp.700.0001.000.000 per kg.

Rantai pasok merupakan aliran material, informasi dan uang yang pokok bahasannya mencakup manajemen sumberdaya yang dimiliki oleh suatu lembaga atau perseorangan, secara terintegrasi untuk mencapai tujuan (Ahumada dan Villalobos, 2009; Corominas, 2017), dalam sub sektor pertanian dikenal dengan istilah farm to the table (Zarei et al., 2011). Secara teknis, manajemen rantai pasok pada produk pertanian lebih komplek (complexity) dibandingan non-pertanian (Sivaramane dan Reddy, 2014), karena sifat produk pertanian yang mudah rusak (perisbale), musiman (seasonal), kamba (bulky), lokasi produksi terpencar dengan kualifikasi mutu beragam (Marimin dan Magfiroh, 2010; Ganeshkumar et al., 2017). Dalam hal ini dapat dikatakan manajemen rantai pasok produk pertanian memiliki risiko yang lebih besar dibandingkan dengan non-pertanian.

Risiko dapat dijelaskan sebagai peluang dari suatu kejadian yang dapat menggagalkan tujuan
(Zsidisin dan Ritchie, 2009; Vanany et al., 2009), bahkan telah diadopsi pada ISO 31000:2009 (Jereb et al., 2012). Penelitian yang membahas risiko rantai pasok produk pertanian antara lain, Suharjito (2011) pada Jagung; Jaya et al. (2014) untuk Kopi Gayo dan Iphov et al. (2014) pada Kakao. Secara teknis, dalam manajemen risiko rantai pasok, pelaku dituntut untuk mampu menggelola risiko, agar dampak (severity) risiko dapat dihindari atau diminimalisasi. Salah satu teknis yang dapat digunakan adalah Failure Mode and Effective Critically Analysis (FMECA). Beberapa penelitian dengan mengaplikasikan teknik FMECA antara lain Chin et al. (2009) dan Muzakkir et al. (2015), walaupun pada produk non pertanian.

Berdasarkan observasi lapang, diketahui bahwa sistem rantai pasok pala di Aceh Selatan mencakup pada produk minyak atsiri (minyak pala), pala bumbu dan olahan pangan pala. Dalam kajian ini fokus pada analisis dan mitigasi risiko rantai pasok minyak pala. Justifikasi dari hal ini adalah risiko kegagalan supplier pada masing-masing pelaku diduga masih sangat tinggi, karena faktor tingginya serangan hama dan penyakit dan faktor ketidakpastian eksportir dalam pembelian minyak pala, akibat penentuan harga dan spesifikasi mutu yang sepihak.

Berdasarkan hal tersebut, dapat disusun Problem statement kajian adalah seperti apa faktorfaktor risiko yang paling berpengaruh terhadap efektivitas sistem rantai pasok pala dan seperti apa skenario mitigasi yang diperlukan. Titik tolak kajian berawal dugaan tingginya risiko usaha penyediaan minyak pala, terutama pada pelaku lokal, petanipenyuling, sehingga diperlukan suatu kajian mendalam dari sisi manajemen risiko. Tujuan penelitian adalah menentukan faktor-faktor dan skenario mitigasi risiko rantai pasok minyak pala di Aceh Selatan.

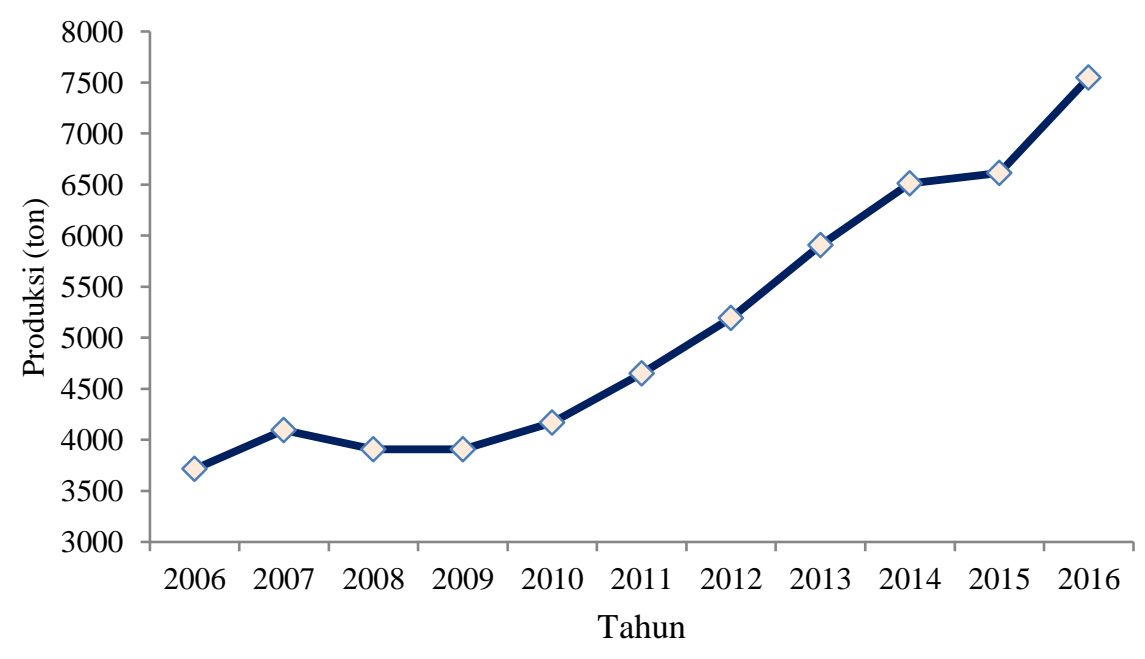

Gambar 1. Trend produksi pala di Aceh Selatan 1 dekade terakhir 


\section{METODE PENELITIAN}

\section{Kerangka Pemikiran}

Dasar pelaksanaan kajian ini adalah adanya dugaan tingginya risiko dalam sistem rantai pasok minyak pala. Kegagalan sistem rantai pasok minyak pala berakibat pada keberlanjutan perekonomian di Aceh Selatan. Dalam rangka pencapaian tujuan manajemen rantai pasok minyak pala, kajian ini membahas 2 pokok bahasan (Gambar 2), yaitu penentuan faktor-faktor risiko pada masing-masing pelaku dan interaksinya, serta menyusun skenario mitigasi risiko yang dapat diterapkan. Model yang dikembangkan berbasis pada analisis struktur rantai pasok minyak pala, pelaku dan aktivitas pelaku. Tahap selanjutnya adalah melakukan analisis titik kritis risiko dengan teknik FMECA.

\section{Tahapan Penelitian}

Teknis pelaksanaan kajian (Gambar 3), diawali dengan observasi dan identifikasi terhadap kondisi eksisting sistem rantai pasok minyak pala di Aceh Selatan. Keluaran (outputs) dari tahap ini adalah struktur, pelaku, aktivitas dan interaksinya dalam sistem rantai pasok. Selanjutnya melakukan penyusunan kuesioner berbasis teknik FMECA (Bertolini et al., 2006). Inti teknik ini adalah aspek yang berpengaruh terhadap potensi (risiko) kegagalan elemen sistem rantai pasok, yang dinyatakan pada severity $(\mathrm{S})$, occurrence $(\mathrm{O})$ dan detection (D). Ekspresi risiko berdasarkan Risk Priority Numbers (RPN) pada masing-masing faktor risiko, yang dikategorikan rendah, sedang, tinggi dan sangat tinggi, dengan pengkategorian mengacu kepada Yusriana et al. (2015) seperti pada Tabel 1. Nilai RPN didapatkan dengan mengalikan nilai
S,O,D yang telah diberikan oleh pakar sebanyak 3 orang. Nilai yang diberikan untuk S,O,D antara skala 1-10. Angka 1 menunjukan kemungkinan kejadian paling rendah, sedangkan angka 10 menunjukkan kemungkinan kejadian paling tinggi.

Tabel 1. Kategori RPN rantai pasok minyak pala Aceh Selatan

\begin{tabular}{llc}
\hline No. & Nilai RPN & Kategori \\
\hline 1. & $0 \geq X \geq 200$ & Sangat Rendah \\
2. & $200 \geq X \geq 400$ & Rendah \\
3. & $400 \geq X \geq 600$ & Sedang \\
4. & $600 \geq X \geq 750$ & Tinggi \\
5. & $750 \geq X \geq 1000$ & Sangat Tinggi \\
\hline
\end{tabular}

Sumber: Yusriana et al. (2015)

\section{HASIL DAN PEMBAHASAN}

\section{Struktur Rantai Pasok}

Secara umum struktur rantai pasok material minyak pala di Aceh Selatan (Gambar 4) terdiri dari beberapa pelaku dan aktivitas serta level, yang saling berinteraksi satu sama lain. Menurut Chopra dan Meindl (2001), rantai pasok mencakup aktivitas produksi atau jasa, yang melibatkan beberapa pelaku utama dan pendukung, dengan berbagai aktivitas secara terintegrasi, sedangkan pendekatan yang umum digunakan adalah pendekatan sistem (Marimin dan Magfiroh, 2010), karena kompleksitas masalah, kepentingan dan pelaku yang terlibat. Berdasarkan Gambar 4, terlihat bahwa peta aliran material minyak pala diawali dari petani pala, dengan aktivitas utama pada aspek budidaya dan pasca panen, dengan output produk biji pala basah.

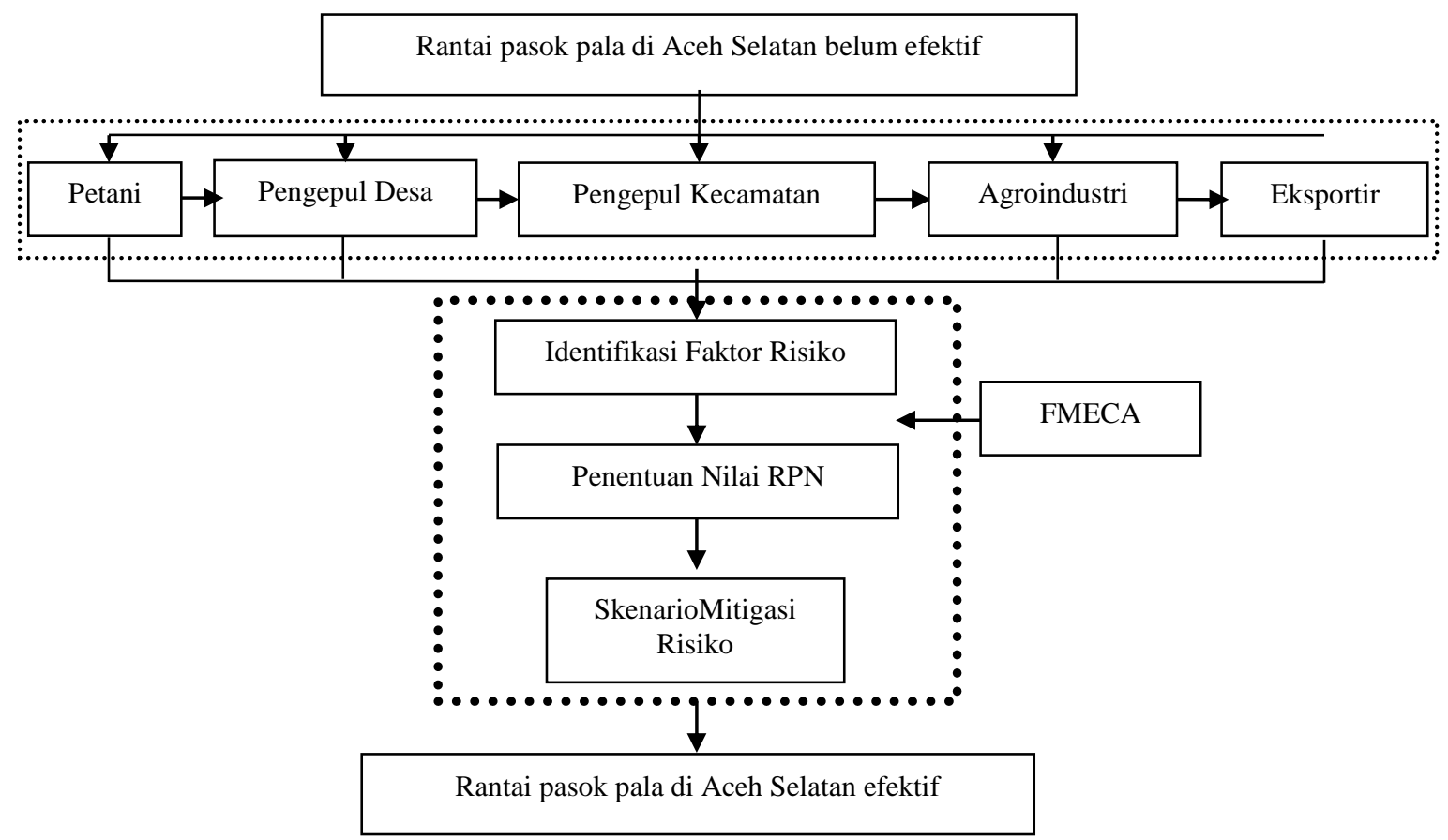

Gambar 2. Kerangka pikir kajian 


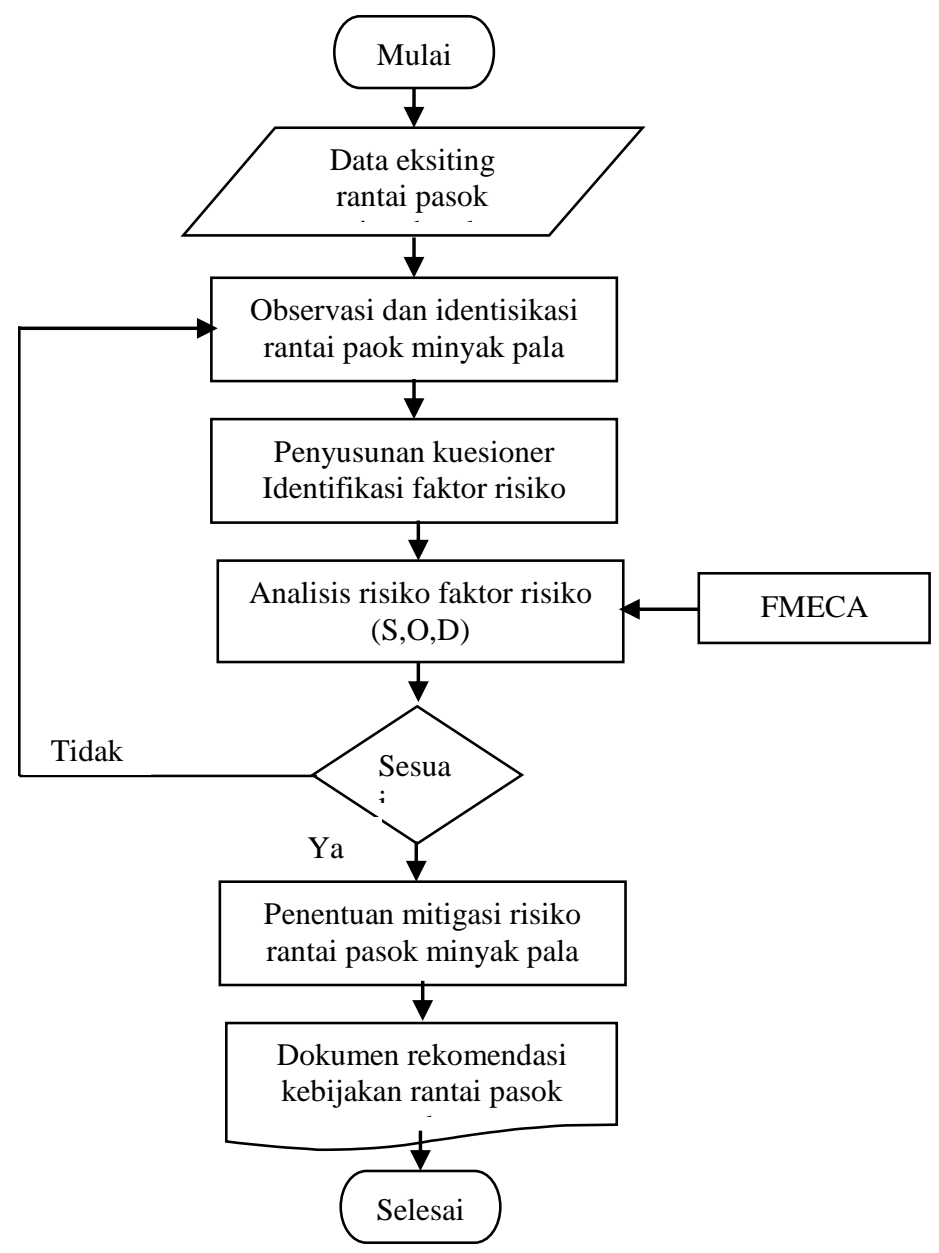

Gambar 3. Diagram alir tahapan penelitian

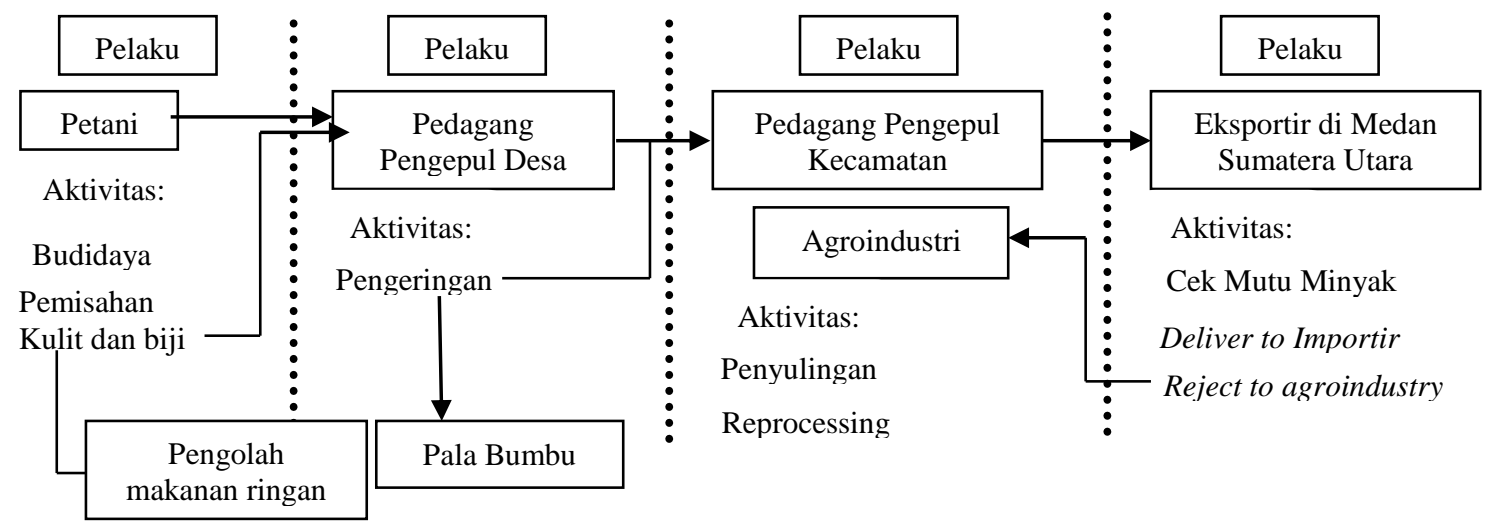

Gambar 4. Struktur dan aktivitas pelaku rantai pasok minyak pala

Selanjutnya adalah pelaku pedagang pengepul desa, dengan aktivitas utama berupa proses pengeringan biji pala, tahap selanjutnya adalah pelaku pedagang pengepul kecamatan yang juga sebagai pelaku industri penyulingan dan tahap terakhir adalah pelaku eksportir di Kota Medan Provinsi Sumatera Utara. Fakta ini merupakan ciri khas dari rantai pasok produk pertanian (agri-supply chain) yang umumnya pihak manufaktur (agroindustri) merupakan titik kritis dalam sistem rantai pasok (Ganeskumar et al., 2017). Titik kritis merujuk pada peran sentral dari pelaku ini, walaupun produk (output) dari pelaku ini setengah jadi (Runtuwene et al., 2015).

Selain sentral pada aliran material, pelaku pedagang pengepul kecamatan juga berperan besar pada aliran uang. Chopra dan Meindl (2001), menyatakan bahwa dalam sistem rantai pasok mencakup aliran material, uang dan informasi. Dalam hal ini, pelaku petani umumnya meminjam modal usaha budidaya dan pasca panen dari pelaku ini atau melalui pedagang pengepul desa. 
Selanjutnya pedagang pengepul desa meminjam modal usaha dari pelaku pedagang pengepul kecamatan yang juga sebagai agroindustri (Gambar 5). Dalam sistem penyiapan modal usaha ini, tidak ada perjanjian khusus, seperti kontraktual/akad, namun hanya kepercayaan (trust), Jaya et al. (2013) menyatakan bahwa, dalam sistem rantai pasok produk pertanian aspek yang paling berpengaruh bukan pada aspek teknis atau ekonomis, tetapi aspek sosial, karena pada umumnya struktur lingkungan telah terbentuk sistem sosial berbasis kemasyarakatan berlandaskan agama.

\section{Identifikasi Faktor-faktor dan Titik Kritis Risiko Rantai Pasok}

Dalam kajian ini fokus utama kegiatan adalah menentukan faktor-faktor risko dan titik-titik kritis dari faktor risiko tersebut. Teknik yang digunakan adalah FMECA (Bertolini, 2006). Teknik ini terdiri dari 2 tahap, Failure Mode and Effect Analysis (FMEA) untuk mengidentifikasi penyebab terjadinya kehilangan efisiensi dan efektivitas dalam sistem rantai pasok dan Criticality Analisys (CA) untuk menilai risiko, menentukan kejadian, serta kepelikan/kesulitan berdasarkan pada masingmasing titik kegagalan yang telah ditetapkan sebelumnya. Evaluasi terhadap titik kegagalan dapat dilakukan dengan menggunakan dua pendekatan yang berbeda yaitu Critically Number (CN) atau Risk Priority Number (RPN). Secara lengkap faktorfaktor risiko pada sistem rantai pasok minyak pala, disajikan pada Tabel 2.

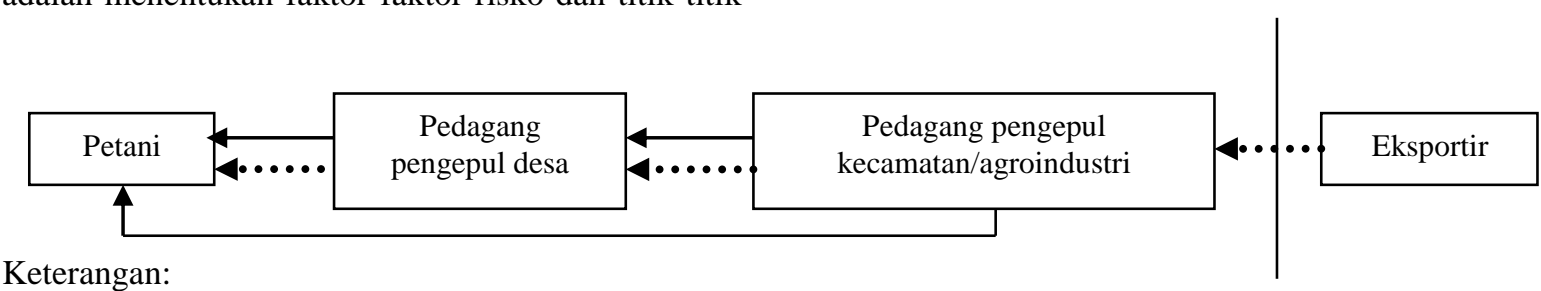

Keterangan:

$\longrightarrow$ Hubungan aliran uang (trust)

$\cdots$ Hubungan aliran uang pembayaran (cash)

Gambar 5. Sistem peminjaman modal usaha pada rantai pasok pala di Aceh Selatan

Tabel 2. Faktor-faktor risiko pada sistem rantai pasok minyak pala Aceh Selatan

\begin{tabular}{|c|c|c|c|c|}
\hline No. & Pelaku & Faktor Risiko & RPN & Kategori \\
\hline 1. & Petani & $\begin{array}{l}\text { - Ketersediaan bibit } \\
\text { - Ketersediaan saprodi pertanian } \\
\text { - Hama dan penyakit tanaman } \\
\text { - Panen } \\
\text { - Pemisahan kulit dan biji } \\
\text { - Fluktuasi harga jual }\end{array}$ & $\begin{array}{l}252 \\
288 \\
900 \\
210 \\
120 \\
810\end{array}$ & $\begin{array}{l}\text { R } \\
\text { R } \\
\text { ST } \\
\text { R } \\
\text { SR } \\
\text { ST }\end{array}$ \\
\hline 2. & Pedagang Pengepul Desa & $\begin{array}{l}\text { - } \text { Proses pengeringan } \\
\text { - } \text { Pemenuhan target produk } \\
\text { - } \text { Pengembalian dana pinjaman ke petani } \\
\text { - } \text { untuk modal produksi } \\
\end{array}$ & $\begin{array}{l}392 \\
504 \\
576 \\
640\end{array}$ & $\begin{array}{l}\text { R } \\
\text { S } \\
\text { S } \\
\text { T }\end{array}$ \\
\hline 3. & $\begin{array}{l}\text { Pedagang Pengepul } \\
\text { Kecamatan sekaligus } \\
\text { agroindustri }\end{array}$ & 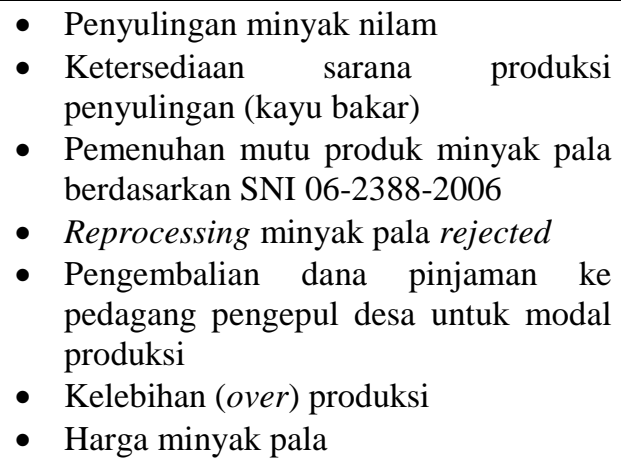 & $\begin{array}{l}648 \\
729 \\
810 \\
720 \\
640 \\
810 \\
729\end{array}$ & $\begin{array}{c}\mathrm{T} \\
\mathrm{T} \\
\mathrm{ST} \\
\mathrm{T} \\
\mathrm{T}\end{array}$ \\
\hline 4. & Eksportir & $\begin{array}{l}\text { - Pemenuhan mutu produk minyak pala } \\
\text { sesuai dengan permintaan importir } \\
\text { - Perubahan kebijakan perdagangan } \\
\text { minyak pala } \\
\text { - Fluktuasi harga minyak pala dunia } \\
\end{array}$ & $\begin{array}{l}729 \\
576 \\
900\end{array}$ & $\begin{array}{l}\mathrm{T} \\
\mathrm{S} \\
\mathrm{ST}\end{array}$ \\
\hline
\end{tabular}


Berdasarkan hasil analisis titik kritis (RPN) pada masing pelaku dalam sistem rantai pasok minyak pala Aceh Selatan terlihat bahwa pada pelaku petani, titik kritis tertinggi adalah pada serangan hama dan penyakit (900) serta fluktuasi harga minyak pala (810), dengan kategori Sangat Tinggi. Serangan hama dan penyakit mengacu kepada aktivitas budidaya berupa serangan hama, dalam hal ini penggerek batang dan penyakit, yaitu jamur akar putih (JAP). BPTP Aceh (2018) dan Harni et al. (2011) melaporkan bahwa $80 \%$ tanaman pala di kawasan Aceh Selatan rusak akibat serangan hama penggerek batang dan penyakit JAP. Hal inilah yang mendasari beberapa stakeholder berusaha keras untuk mengatasi serangan ini, beberapa inovasi teknologi yang diaplikasikan antara lain penggunaan bibit sambung pucuk dengan batang bawah pala hutan

Pada pelaku pedagang pengepul desa, titik kritis berada pada fluktuasi harga jual (640) dengan kategori tinggi. Dalam hal ini mengacu kepada harga jual produk biji pala kering dari pelaku ini ke agroindustri. Secara teknis harga jual biji pala kering, juga dipengaruhi oleh harga minyak pala di level agroindustri.

Dalam sistem rantai pasok, umumnya pelaku ini memiliki risiko usaha yang paling kecil di antara pelaku lainnya, seperti petani, agroindustri dan eksportir. Akan tetapi, secara emosional dan sosial pelaku pedagang pengepul desa memiliki peran penting dalam pemenuhan produk biji pala kering. Pemenuhan juga mencakup time-delivery yang justru sulit dipenuhi oleh petani jika langsung berhubungan dengan agroindustri. Marimin (2010), menyatakan bahwa faktor penghambat (barrier) dari produk pertanian adalah musiman, kamba, mutu beragam dan lokasi panen yang terpencar. Disinilah peran penting dari pelaku pedagang pengepul desa. Berdasarkan hasil analisis FMECA, terlihat bahwa titik kritis terdapat pada pelaku pedagang pengepul kecamatan yang umumnya juga sebagai agroindustri penyulingan minyak pala. Seluruh aktivitas yang dilaksanakan oleh pelaku ini memiliki kategori risiko tinggi dan sangat tinggi. Hal ini menunjukkan peran penting dalam sistem rantai pasok, sekaligus juga penanggung utama risikonya. Secara teknis, peran penting pelaku ini, pada penyediaan modal usaha bagi petani melalui pedagang pengepul desa dan pada proses perdagangan minyak pala dengan pelaku eksportir. Runtuwene et al. (2015), menyatakan bahwa dalam sistem rantai pasok pala, peran pelaku pengepul kecamatan sangat penting, yaitu sebagai mitra utama agroindustri dalam pemenuhan mutu produk dan time-delivery.

Dari sisi, proses produksi peran penting dari pelaku pedagang pengepul kecamatan yang juga sebagai agroindustri, titik kritisnya adalah pemenuhan mutu minyak pala yang mengacu kepada SNI 06-2388-2006, selain itu juga aspek ketersediaan bahan bakar penyulingan yang menggunakan kayu bakar. Fakta ini berhubungan erat dengan semakin berkurangnya pasokan kayu, akibat hutan produksi yang semakin mengecil. Selain itu $80 \%$ wilayah Aceh Selatan masuk ke dalam Taman Nasional Leuser. Dari sisi teknis Mustafril (2017), menyatakan umumnya karaktersitik mutu minyak pala yang dihasilkan sudah sesuai dengan permintaan pasar (SNI-062388-2006). Hal ini terjadi karena dalam proses penyulingan telah menggunakan bahan anti karat (stainless), dengan spesifikasi untuk produk pangan.

Berdasarkan aspek tata niaga, pelaku agroindustri juga menanggung risiko kegagalan dari penjualan produk minyak pala ke eksportir di Medan. Fakta ini dengan penjelasan, bahwa minyak yang sudah dihasilkan kemudian dikirim ke eksportir, pihak eksportir melakukan uji mutu minyak yang harus sesuai spesifikasi mutu importir atau setidaknya mengacu kepada SNI-06-2388-2006. Jika mutu minyak yang dikirim ke eksportir tidak sesuai dengan spesifikasi mutu, maka minyak ditolak oleh eksportir. Dalam hal ini agroindustri harus menanggung biaya transportasi untuk membawa kembali minyak ke Aceh Selatan, selanjutnya dilakukan reprocessing dan melakukan pengiriman kembali ke eksportir. Rata-rata 1 orang pelaku agroindustri melakukan pengiriman minyak pala ke eksportir di Medan, sebanyak 1 drum (210 L) per bulan. Saat dilakukan kajian harga minyak pala di tingkat eksportir Rp. 610.000/kg, harga tertinggi minyak pala di Aceh Selatan mencapai Rp.1.000.000/ kg dan terendah Rp. 550.000/kg.

Dari pelaku eksportir, risiko terbesar terdapat pada fluktuasi harga minyak pala dunia. Fluktuasi terjadi akibat ketidakpastian pasokan minyak atsiri dunia, fluktuasi juga dipengaruhi oleh iklim kebijakan masing-masing negara, baik produsen maupun konsumen. Harga juga dipengaruhi oleh semakin meningkatnya penggunaan minyak pala, yang kandungan utamanya adalah Miristin (Suprihatin et al., 2007), terutama sekali pada bidang farmasi.

\section{Mitigasi Risiko}

Dalam suatu kajian yang membahas aspek risiko, tentunya diharuskan untuk merancang skenario mitigasinya. Pada sistem rantai pasok minyak pala di Aceh Selatan, risiko dibahas berdasarkan sistem aliran material yang mencakup pelaku petani, pedagang pengepul desa, pedagang pengepul kecamatan yang juga sebagai agroindustri dan eksportir. Dalam perspektif rantai pasok, mitigasi risiko adalah tindakan yang dilakukan oleh pelaku rantai pasok untuk meminimalisasi dampak risiko yang terjadi pada suatu kejadian (Hariharan et al., 2018). Berdasarkan hasil identifikasi dan penilaian risiko masing-masing pelaku dapat dielaborasi bahwa untuk pelaku petani mitigasi yang dapat diaplikasikan untuk mengatasi serangan hama 
penggerek batang dan penyakit jamur akar putih adalah dengan menggunakan bibit sambung pucuk, dengan batang bawah pala hutan endemik di Aceh Selatan, sedangkan tunas air (entres) menggunakan pala lokal hasil tinggi (BPTP Aceh, 2018).

Pada pelaku pedagang pengepul desa, risiko tertinggi adalah fluktuasi harga jual pala yang ditentukan oleh eksportir di Medan. Salah satu opsi mitigasi yang dapat diaplikasikan adalah dengan kontrak tani atau penjualan. Opsi ini juga berlaku untuk pelaku petani dan agroindustri. Jaya et al. (2014) menyatakan bahwa alternatif terbaik dalam mengatasi risiko harga dalam sistem rantai pasok produk pertanian adalah melalui kontrak tani, yang disepakati oleh masing-masing pelaku. Untuk pelaku pedagang pengepul kecamatan yang juga sebagai agroindustri, risiko tertinggi pada pemenuhan mutu minyak pala yang sesuai dengan permintaan (spesifikasi) eksportir. Kegagalan pemenuhan mutu, menyebabkan minyak pala yang sudah dikirim harus dikembalikan dan dilakukan reprocessing, untuk menghindari kerugian yang lebih besar. Pada sisi yang lain, pelaku ini juga harus menanggung risiko over produksi, akibat pasokan dari daerah lain. Hal ini juga salah satu penyebab turunnya harga jual minyak pala, dan penolakan dari eksportir.

\section{Implikasi Manajerial}

Salah satu kunci pendayagunaan hasil penelitian adalah diaplikasikannya hasil penelitian tersebut ke para pengguna. Dalam hal ini mengacu kepada para pelaku sistem rantai pasok minyak pala. Hasil berupa analisis dan mitigasi risiko, didiskusikan pada kegiatan diseminasi hasil penelitian yang dihadiri oleh pelaku rantai pasok dan para pemangku kepentingan pengembangan pala di Aceh Selatan. Sintesa aspek teknis dan kebijakan dirumuskan sebagai implikasi manajerial yang merupakan bagian tak terpisahkan dari penelitian yang dilaksanakan.

Dalam peningkatan efektivitas dan efisiensi sistem rantai pasok minyak pala, diperlukan sinergitas pelaku rantai pasok dan pemangku kepentingan dari unsur pemerintah pusat, daerah, lembaga swadaya masyarakat (LSM). Berdasarkan hasil analisis dan mitigasi risiko, terlihat bahwa titik kunci sistem berada pada pihak agroindustri minyak pala. Pelaku ini memiliki pengaruh besar baik ke hulu (petani) dan ke hilir (eksportir), akan tetapi pelaku ini juga memiliki risiko tinggi terhadap usaha yang dilaksanakan. Pada sisi yang lain, pelaku ini juga yang memiliki tingkat keuntungan yang terbesar dibandingkan dengan pelaku lain. Dalam hal ini penting bagi pemangku kepentingan untuk memberikan insentif. Insentif dapat berupa kemudahan untuk mendapatkan akses permodalan, bimbingan teknis peningkatan mutu produk dan manajemen. Berdasarkan tingginya fluktuasi harga minyak pala, perlu juga inisiasi pembentukan badan usaha yang mampu mengendalikan pasokan minyak pala ke eksportir di Medan. Badan usaha ini sepenuhnya berorientasi profit, dengan pelaku murni dari kalangan pengusaha, sedangkan pemerintah hanya sebagai inisiator yang memberikan insentif kemudahan investasi dan keringanan pajak (tax holiday).

\section{KESIMPULAN DAN SARAN}

\section{Kesimpulan}

Faktor-faktor risiko pada sistem rantai pasok minyak pala Aceh Selatan mencakup pada pelaku petani yaitu serangan hama dan penyakit. Pada pelaku pedagang pengepul desa adalah fluktuasi harga, pelaku agroindustri berupa pemenuhan mutu produk dan over produksi minyak pala.

Mitigasi yang dapat diaplikasikan untuk pelaku petani dengan mengintroduksi bibit sistem sambung pucuk, sedangkan untuk pelaku agroindustri dengan aplikasi sistem kontrak tani yang mencakup aspek mutu, jumlah, harga dan timedelivery.

\section{UCAPAN TERIMA KASIH}

Tim peneliti mengucapkan terima kasih kepada Kepala Dinas Pertanian dan Perkebunan Provinsi Aceh, Kepala Dinas Pertanian Kabupaten Aceh Selatan, Bappeda Kabupaten Aceh Selatan dan Kepala Bidang Perkebunan Dinas Pertanian dan Perkebunan yang telah membantu pelaksanaan penelitian ini.

\section{DAFTAR PUSTAKA}

Ahumada O dan Villalobos JR. 2009. Application of planning models in the agri-food supply chain: A Review. European Journal Operational Research. 195:1-20.

Balai Pengkajian Teknologi Pertanian Aceh. 2018. Kajian Pengembangan Bibit Pala Pola Sambung Pucuk Aceh Selatan. Kerjasama Dinas Pertanian dan Perkebunan Provinsi Aceh dengan Balai Pengkajian Teknologi Pertanian Aceh.[belum dipublikasi], Banda Aceh.

Bertolini M, Maurizio B, dan Oberto M. 2006. FMECA approach to product tracebility in the food industry. Journal Food Control. 17:137-145.

BPS. 2017. Kabupaten Aceh Selatan Dalam Angka, Tapaktuan.

Corominas A. 2017. Research into the Area of Supply Chain. Omnia Science.

Chin KW, Wang YM, Poon KKK, Yang JO. 2009. Failure mode and effects analysis using a group-based evidential reasoning approach. Computers \& Operations Research. 36:1768-1779. 
Chopra S dan Meindl P. 2001. Supply Chain Management: Strategy, Planning, and Operations. New Jersey - Prentice-Hall.

Direktorat Jenderal Perkebunan. 2017. Statistik Perkebunan Indonesia. Jakarta.

Ganeshkumar C, Pachayappan M, dan Madanmohan G. 2017. Agri-food supply chain management: literature review. Intelligent Information Management. 9: 68-96.

Harni R, Trisawa IM, dan Wahyudi A. 2011. Observasi dan identifikasi penyakit jamur akar pada tanaman pala di Kabupaten Aceh Selatan. Buletin RISTRI. 2 (3): 383-390.

Iphov KS, Yandra A, Syah D, Marimin. 2014. Analisa dan mitigasi risiko rantai pasok agroindustri kakao yang berkelanjutan. Jurnal Industri Hasil Perkebunan. 9 (2): 69-79.

Jaya R, Machfud, Raharja S, Marimin. 2013. Sustainability analysis for Gayo Coffee Supply Chain. International Journal Advances on Advanced Science, Engineering and Information Technology. 3 (2): 24-28.

Jaya R, Machfud, Raharja S, Marimin. 2014. Analisis dan mitigasi risiko rantai pasok kopi gayo berkelanjutan dengan pendekatan fuzzy. Jurnal Teknologi Industri Pertanian. 24 (1): 61-71.

Jereb B, Cvahte T, dan Rosi B. 2012. Mastering supply chain risks. Serbian Journal Management. 7 (2): $271-285$.

Kalay AM, Lamerkabel JSA, dan Thenu FJL. 2015. Kerusakan tanaman pala akibat serangan penyakit busuk buah kering dan hama penggerek batang pala di Kecamatan Leihitu Kabupaten Maluku Tengah. Jurnal Agroekotek. 7 (2): 138-146.

Marimin. 2004. Pengambilan Keputusan Kriteria Majemuk: Teknik dan Aplikasi. Jakarta: Penerbit Grasindo.

Marimin dan Maghfiroh N. 2010. Aplikasi Teknik Pengambilan Keputusan dalam Manajemen Rantai Pasok. Bogor: IPB-Press.

Mustafril. 2017. Karakteristik mutu minyak pala berdasarkan peralatan distilasi drum bekas dan distilasi stainless (studi kasus di kabupaten Aceh Selatan). Jurnal Rona Teknik Pertanian. 10 (2): 35-46.
Muzakkir SM, Lijesh KP, dan Hirani H. 2015. Failure mode and effect analysis of journal bearing. International Journal Applied Engineering Research. 10 (16): 3684336850.

Runtuwene EC, Pasuhuk AS, Jan ABH. 2015. Efisiensi desain jaringan manajemen rantai pasokan pala di Kabupaten Sangihe (Studi kasus pada komoditi pala Di Kecamatan Kendahe). Jurnal Berkala Efisiensi. 15 (5): 767-776.

Sivaramane N dan Reddy GP. 2014. Natio nal Academy of Agricultural Research Management (NAARM) Rajendranagar, Hyderabad 500030, Telangana, India.

Standar Nasional Indonesia (SNI). 2006. 06-23882006. Minyak Pala. Badan Standarisasi Nasional, Jakarta.

Suharjito. 2011. Pemodelan sistem pendukung pengambilan keputusan cerdas manajemen risiko rantai pasok produk/komoditi jagung [Disertasi]. Bogor: Sekolah Pascasarjana Institut Pertanian Bogor.

Suprihatin, Ketaren S. Ngudiwaluyo, Friyadi A. 2007. Isolasi miristisin dari minyak pala (myristica fragrans) dengan metode penyulingan uap. Jurnal Teknologi Industri Pertanian. 17 (1): 23-28.

Vanany I, Zailani S, dan Pujawan N. 2009. Supply chain risk management: literature review and future research. International Journal Information Systems and Supply Chain Management. 2(1):16-33.

Yusriana. 2015. Rancang bangun sistem ketertelusuran cerdas untuk rantai pasok kakao Aceh. [Disertasi]: Institut Pertanian Bogor.

Zarei M, Fakhrzad MB, dan Paghaleh MJ. 2011. Food supply chain leanness using a developed QFD model. Journal Food Engineering. 102: 25-33.

Zsidisin G dan Ritchie B. 2009. Supply Chain Risk: Development, Issues and Challenges $\underline{d i}$ dalam, Supply Chain Risk: A Handbook of Assessment, Management, and Performance [edited] Zsidisin, G. and B. Ritchie. Springer, New York. 